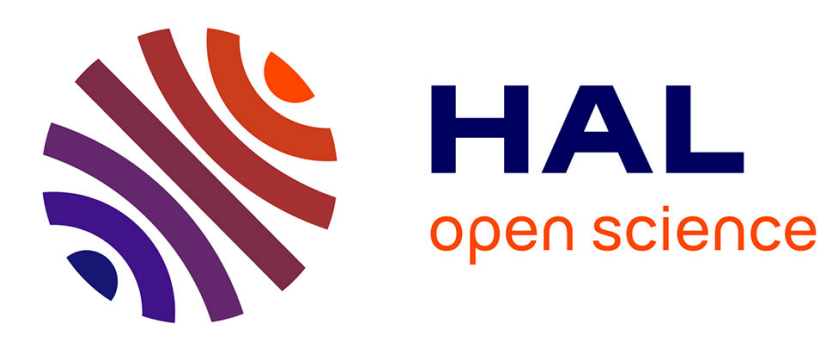

\title{
biological forcing controls the chemistry of reef-building coral skeleton
}

\author{
A. Meibom, S. Mostefaoui, J.P. Cuif, Y. Dauphin, F. Houlbreque, R. Dunbar, \\ B. Constantz
}

\section{- To cite this version:}

A. Meibom, S. Mostefaoui, J.P. Cuif, Y. Dauphin, F. Houlbreque, et al.. biological forcing controls the chemistry of reef-building coral skeleton. Geophysical Research Letters, 2007, 34, pp.1026014. hal-00376817

\section{HAL Id: hal-00376817 \\ https://hal.science/hal-00376817}

Submitted on 2 Jun 2021

HAL is a multi-disciplinary open access archive for the deposit and dissemination of scientific research documents, whether they are published or not. The documents may come from teaching and research institutions in France or abroad, or from public or private research centers.
L'archive ouverte pluridisciplinaire HAL, est destinée au dépôt et à la diffusion de documents scientifiques de niveau recherche, publiés ou non, émanant des établissements d'enseignement et de recherche français ou étrangers, des laboratoires publics ou privés. 


\title{
Biological forcing controls the chemistry of reef-building coral skeleton
}

\author{
Anders Meibom, ${ }^{1}$ Smail Mostefaoui, ${ }^{1}$ Jean-Pierre Cuif, ${ }^{2}$ Yannicke Dauphin, ${ }^{2}$ \\ Fanny Houlbreque, ${ }^{1,3}$ Robert Dunbar, ${ }^{3}$ and Brent Constantz ${ }^{3}$ \\ Received 1 November 2006; revised 1 December 2006; accepted 8 December 2006; published 16 January 2007.
}

[1] We present analyses of major elements $\mathrm{C}$ and $\mathrm{Ca}$ and trace elements $\mathrm{N}, \mathrm{S}, \mathrm{Mg}$ and $\mathrm{Sr}$ in a Porites $s p$. exoskeleton with a spatial resolution better than $\sim 150 \mathrm{~nm}$. Trace element variations are evaluated directly against the ultrastructure of the skeleton and are ascribed to dynamic biological forcing. Individual growth layers in the bulk fibrous aragonite skeleton form on sub-daily timescales. Magnesium concentration variations are dramatically correlated with the growth layers, but are uncorrelated with $\mathrm{Sr}$ concentration variations. Observed (sub)seasonal relationships between water temperature and skeletal traceelement chemistry are secondary, mediated by sensitive biological processes to which classical thermodynamic formalism does not apply. Citation: Meibom, A., S. Mostefaoui, J.-P. Cuif, Y. Dauphin, F. Houlbreque, R. Dunbar, and B. Constantz (2007), Biological forcing controls the chemistry of reef-building coral skeleton, Geophys. Res. Lett., 34, L02601, doi:10.1029/2006GL028657.

\section{Introduction}

[2] Coral-derived paleoclimate reconstructions are empirically based on observations that skeletal oxygen isotopic composition and certain trace-element abundances (e.g., $\mathrm{Sr}$ and $\mathrm{Mg}$ ) vary in response to changes in water temperature. Traditionally, equilibrium thermodynamics has been invoked to explain these relationships [Epstein et al., 1953; Mitshuguchi et al., 1996; Smith et al., 1979; Swart and Leder, 1996]. However, a detailed understanding of the biomineralization process is lacking and a critical question is the role of biological processes in controlling skeletal composition. Without such knowledge, it is difficult to quantitatively assess the general applicability and precision of coral-based paleoclimate reconstructions.

[3] Reef-building coral skeletons consist primarily of fibrous aragonite. Understanding the level of biological influence over the chemistry and growth of this skeletal component is the focus of this study. A number of recent micro-analytical studies of coral skeletons have uncovered large amplitude chemical variations that cannot be ascribed to external environmental variability [Allison, 1996; Allison et al., 2005; Cohen et al., 2001; Cuif et al., 2003; Hart and

\footnotetext{
${ }^{1}$ Laboratoire d'Etude de la Matiere Extraterrestre USM 0205, Muséum National d'Histoire Naturelle, Paris, France.

${ }^{2}$ UMR 8148, Interactions et Dynamique des Environnement de Surface, Université Paris XI, Orsay, France.

${ }^{3}$ Department of Geological and Environmental Sciences, Stanford University, Stanford, California, USA.
}

Cohen, 1996; Meibom et al., 2003, 2006; Sinclair, 2005]. Until recently it has not been possible to perform sensitive chemical analysis at the sub-micrometer length scales that are characteristic of the skeletal ultra-structure, which could provide a deeper insight into the skeletal growth processes.

\section{Results}

[4] Porites is the most frequently used coral genus for paleoenvironmental reconstructions. With the NanoSIMS N50 ion microprobe at the Muséum National d'Histoire Naturelle a chemical analysis of a Porites $s p$. skeleton has been carried out. Materials and methods are discussed in the auxiliary material ${ }^{1}$. As a guide to the analyses, the Porites $s p$. skeletal architecture is shown in Figure 1. Figure 2 shows the NanoSIMS data accompanied by an SEM image of the corresponding skeleton. The NanoSIMS traverse starts at the edge of the skeleton and proceeds to the right - towards the interior. It passes close to, but does not cross a center of calcification (COC), which is visible in the right hand side of the SEM image.

[5] Magnesium exhibits dramatic variability in the layered fibrous aragonite. Over length scales of $2-5 \mu \mathrm{m}$, the $\mathrm{Mg} / \mathrm{Ca}$ ratio changes from $\sim 4 \mathrm{mmol} / \mathrm{mol}$ to $>7.5 \mathrm{mmol} / \mathrm{mol}$ (Figure 2). Qualitatively, these variations are similar to those observed previously in Pavona sp. [Meibom et al., 2004], but the $\mathrm{Mg} / \mathrm{Ca}$ variations recorded in this Porites specimen are of larger magnitude: the total range in $\mathrm{Mg} / \mathrm{Ca}$ spans a factor of three. These oscillating $\mathrm{Mg} / \mathrm{Ca}$ variations are not due to large variations in the ${ }^{40} \mathrm{Ca}^{+}$signal, which typically varies less than $\sim 5 \%$ on similar length scales and does not correlate with the $\mathrm{Mg}$ signal (Figure 3c). $\mathrm{Mg} / \mathrm{Ca}$ oscillations therefore reflect variations in $\mathrm{Mg}$ concentration within the skeleton. Furthermore, the $\mathrm{Mg} / \mathrm{Ca}$ oscillations are spatially correlated with components of the layered ultrastructure of the fibrous aragonite. While previous studies have investigated the distribution and speciation of $\mathrm{Mg}$ in biogenic calcite [Davis et al., 2004] very little work has focused on the role that Mg plays in aragonite biomineralization. Dissolution experiments on coral skeletons suggest that $\mathrm{Mg}$ occurs in a dispersed mineral phase that is more soluble than aragonite [Amiel et al., 1973]. It has also been suggested that the $\mathrm{Mg} / \mathrm{Ca}$ fluctuations might be a signature of the production of an amorphous calcium carbonate phase [Meibom et al., 2004] that is transiently stable during skeletal formation [Weiner et al., 2003]. The identification of a distinct high-Mg phase in the fibrous aragonite skeleton is an important research objective. Combined NanoSIMS,

\footnotetext{
${ }^{1}$ Auxiliary materials are available in the HTML. doi:10.1029/ 2006GL028657.
} 


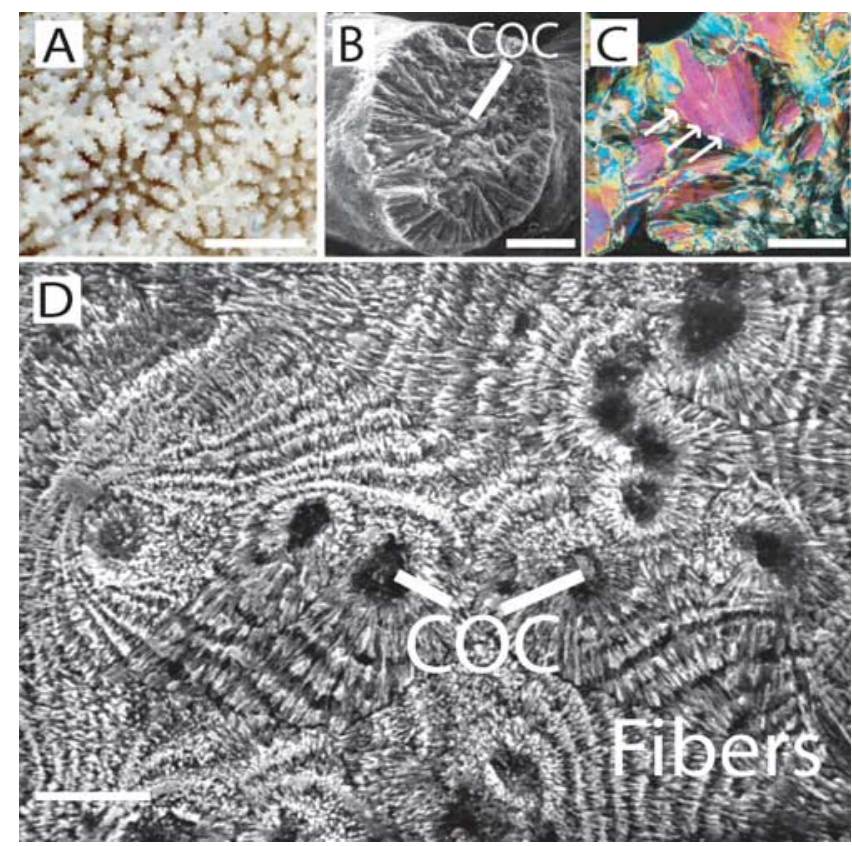

Figure 1. Architecture of the Porites sp. skeleton. (a) Macroscopic morphology of the skeleton after removal of the tissue layer. Growth direction is towards the viewer. The skeleton consists of aligned calices, each consisting of a near circular wall, from which individual septa protrude towards the center. Scale-bar: $\sim 1 \mathrm{~mm}$. (b) SEM image of a broken septa surface showing the characteristic central COC overgrown by fibrous aragonite. Scale-bar: $\sim 100 \mu \mathrm{m}$. (c) Optical microscope image in transmitted and polarized light of a polished thin-section of a septa cut transversely to the growth direction. The fibrous aragonite appears to be organized into bundles (one is indicated by arrows) radiating away from the COC. These fiber bundles are conventionally considered to be the product of 'free crystal growth' from a supersaturated solution [Bryan and Hill, 1941]. (d) SEM image of a septa (cut transversely to the growth direction, polished and etched) reveals that the fibrous aragonite is in fact a complex, layered structure, formed by a cyclic formation of layers each 25 micrometers in thickness [Cuif et al., 2003]. Scale-bar: $\sim 10 \mu \mathrm{m}$.

TEM and synchrotron-based X-ray spectroscopy are under way in an effort to investigate this issue further.

[6] $\mathrm{The} \mathrm{Sr} / \mathrm{Ca}$ ratio also exhibits significant fluctuations along the traverse. Near the edge of the skeleton (left-hand side in Figure 2) several clear $\mathrm{Sr} / \mathrm{Ca}$ oscillations are observed over length scales of $2-5 \mu \mathrm{m}$, with amplitudes up to $\sim 15 \%$ relative to the average $\mathrm{Sr} / \mathrm{Ca}$ ratio. In general, the $\mathrm{Sr} / \mathrm{Ca}$ ratio does not correlate with $\mathrm{Mg} / \mathrm{Ca}$, nor does it correlate clearly with the ultra-structure of the fibrous aragonite. Around $43 \mu \mathrm{m}$ into the traverse there is a sharp positive spike in the $\mathrm{Sr} / \mathrm{Ca}$ ratio that coincides with a broad negative fluctuation in $\mathrm{Mg} / \mathrm{Ca}$ and with positive fluctuations in $\mathrm{N} / \mathrm{C}$ and $\mathrm{S} / \mathrm{C}$, respectively. After this feature, the $\mathrm{Sr} / \mathrm{Ca}$ ratio decreases in the right hand side of the traverse, in the vicinity of the COC.
[7] The distribution of organics in the skeleton is elucidated by the observation that the ${ }^{40} \mathrm{Ca}^{+}$signal correlates negatively with the ${ }^{12} \mathrm{C}^{+}$signal (Figure 3a). A relatively high ${ }^{12} \mathrm{C}^{+}$signal is obtained in the vicinity of the COC, indicating that the abundance of organics increases close to the COC. Sulfur, which is thought to be present in the skeleton primarily as sulfated polysaccharides, is known to increase towards the COC region [Cuif et al., 2003] and our data are consistent with this observation. The $\mathrm{S} / \mathrm{C}$ ratio increases significantly in the right hand side of the traverse (i.e., in the vicinity of the COC), supporting the interpretation that $\mathrm{S}$ is associated primarily with organics. Further-

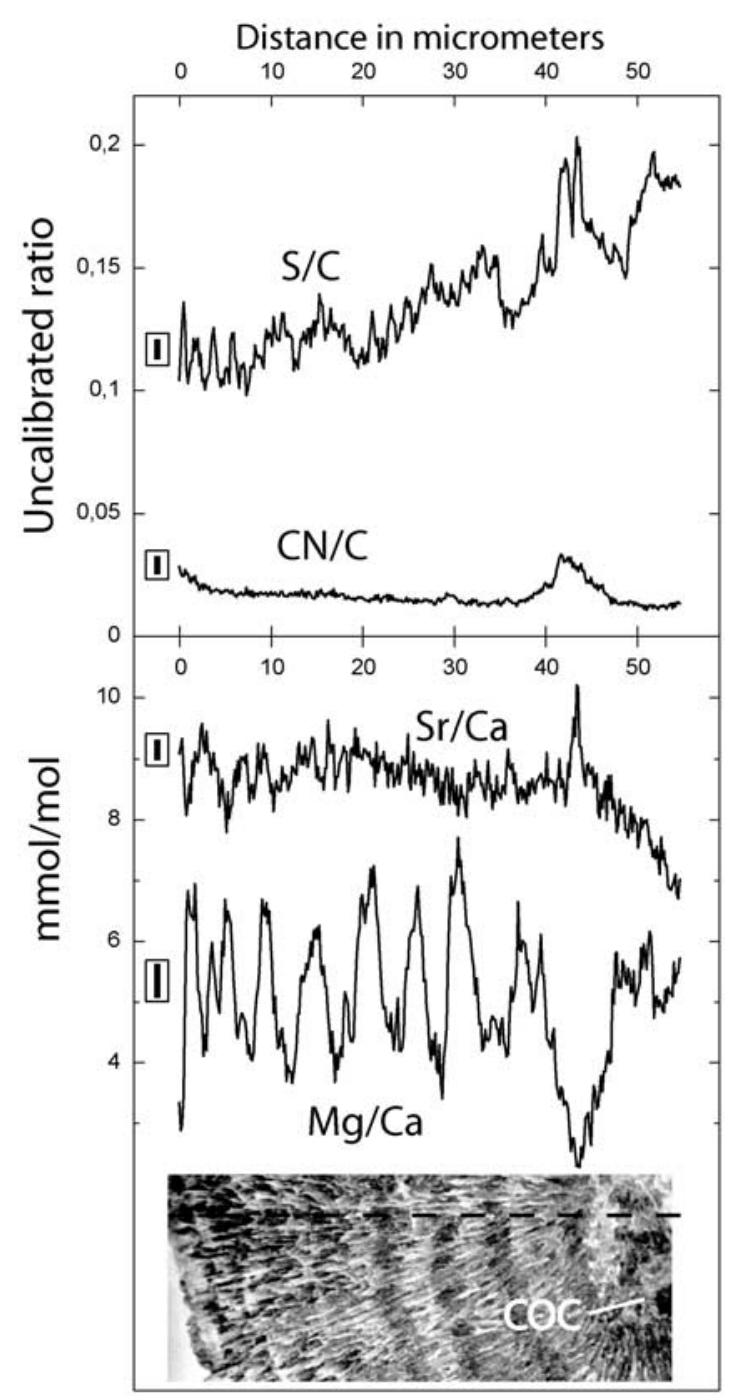

Figure 2. NanoSIMS profiles of $\mathrm{Mg} / \mathrm{Ca}$ and $\mathrm{Sr} / \mathrm{Ca}$ (calibrated), and ${ }^{32} \mathrm{~S} /{ }^{12} \mathrm{C},{ }^{12} \mathrm{C}^{14} \mathrm{~N} /{ }^{12} \mathrm{C}$ (uncalibrated) across a segment of a Porites sp. skeleton. A SEM image of the polished and etched surface of the skeleton traversed by the NanoSIMS is shown below. The hatched line indicates the position of the NanoSIMS traverse. The coral formed this skeleton by adding layers of aragonite onto a skeletal structure that was first formed around the $\mathrm{COC}$ [Cuif and Dauphin, 2005]. The general growth direction is therefore from right to left. Error-bars, shown to the left of each profile (in frames), are $\pm 1 \sigma$. 

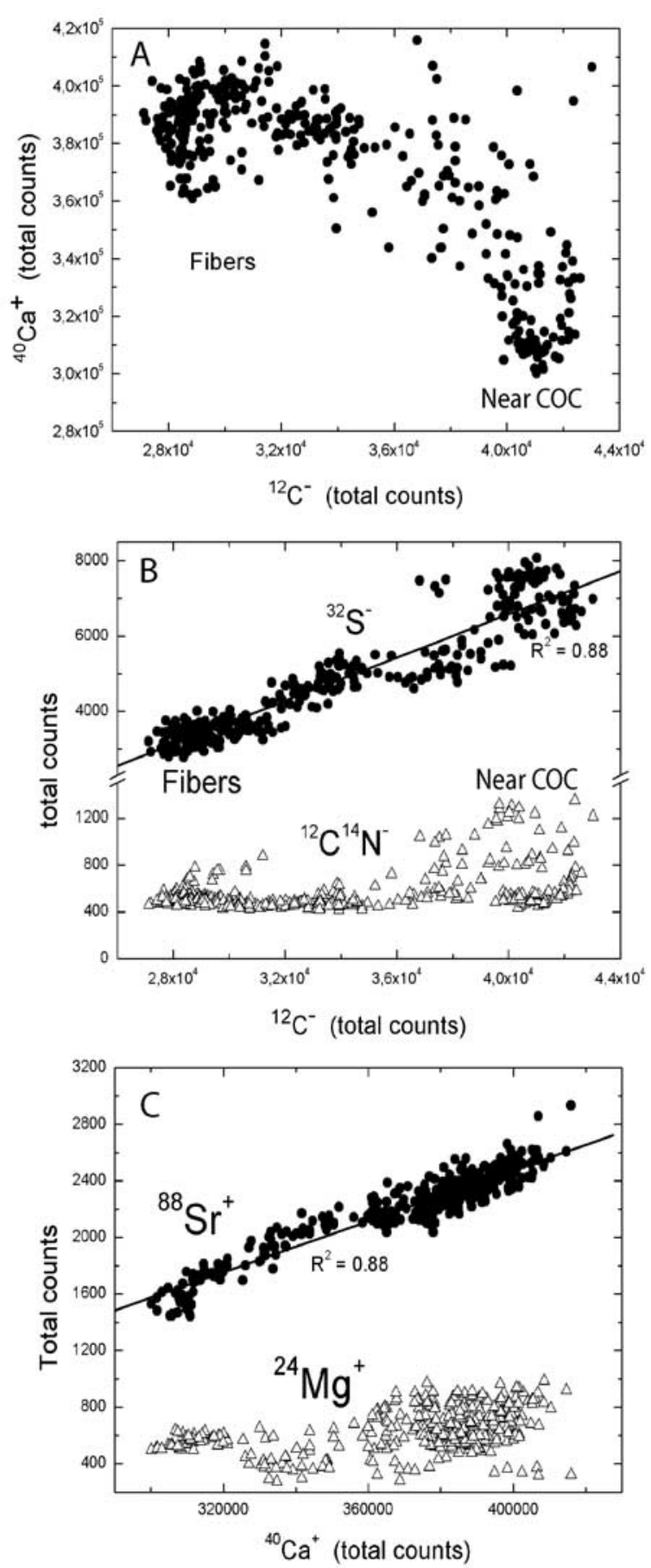

Figure 3. Inter-element relationships from the NanoSIMS traverse in Figure 2. Solid lines are linear fits through the data.

more, the S concentration exhibits clear oscillations (with amplitudes of about $20 \%$ on length scales as short as $1 \mu \mathrm{m}$ ) and exhibits large spikes around $43 \mu \mathrm{m}$ (Figures 2 and $3 \mathrm{~b}$ ). In contrast, $\mathrm{N}$, which is primarily associated with proteinaceous molecules [Constantz and Weiner, 1988], exhibits a flat and featureless distribution with the exception of the positive fluctuation around $43 \mu \mathrm{m}$. Thus, in general, $\mathrm{N}$ is homogeneously distributed in the fibrous parts of the skeleton, at least on length scales comparable to the beam-size of the ion microprobe, here about $100 \mathrm{~nm}$.

\section{Discussion}

[8] The annual extension rate of the Porites coral studied here is $\sim 11 \mathrm{~mm}$, which corresponds to an average daily linear extension rate of $\sim 30 \mu \mathrm{m}$. Seasonal fluctuations in extension rate range from 16 to $46 \mu \mathrm{m} /$ day [Meibom et al., 2003]. The lateral (thickening) growth rate is comparable, certainly for the fibrous skeleton formed close to the COC. Thus, as a first order estimate, assuming a nearly linear growth rate, the growth-time represented by the analyzed skeleton is 1.5 to 3.5 days. There are eight full $\mathrm{Mg} / \mathrm{Ca}$ oscillations corresponding to eight growth layers in Figure 2. This provides a strong indication that individual growth layers are deposited on a timescale significantly shorter than 24 hours. Within the plausible uncertainty of this estimate, it is possible that up to five growth layers are formed in 24 hours. In contrast, it is very unlikely that only one growth layer is formed within a full diurnal cycle. Individual growth layers are therefore the result of a continuous and active biological forcing of the skeletal growth process, as opposed to a passive biological response to the diurnal cycle, a conclusion also reached in several other recent studies [e.g., Clode and Marshall, 2003; Cuif et al., 2003; Meibom et al., 2004; Raz-Bahat et al., 2006; Stolarski, 2003]. Furthermore, the short growth timescale makes it unlikely that the large chemical variations recorded in the skeleton are driven by changes in the external marine environment. Hourly measurements of ocean temperature on a nearby Kenya reef during 1995/1996 reveal diurnal variability of less than $1{ }^{\circ} \mathrm{C}$. In thermodynamic equilibrium between seawater and inorganically precipitated aragonite such temperature variations can induce $\mathrm{Sr} / \mathrm{Ca}$ variations of about 1\% [Kinsman and Holland, 1969], far less than the variations measured here.

[9] Non-biological models for trace element variation in the coral skeleton predict inter-element correlations that are not observed here [e.g., Cohen et al., 2006; Gaetani and Cohen, 2006]. Such 'inorganic' models invoke kinetic fractionations and/or changing levels of super-saturation of a hypothetical reservoir that is assumed to exist between the calicoblastic ectoderm and the surface of the growing skeleton, the so-called "extracytoplasmic calicifying fluid". However, all modern observations of the interface between the skeleton and the calicoblastic ectoderm clearly demonstrate a tight physical contact between the skeleton and the calicoblastic ectoderm, leaving no space for such a reservoir [Brown et al., 1983; Clode and Marshall, 2002; DomartCoulon et al., 2006; Johnston, 1980; Muscatine et al., 1997; Le Tissier, 1990]. Furthermore, none of the non-biological models offer an explanation of the general observation that skeletal chemical and isotopic composition are not uniform over the skeleton. It is an observational fact that $\mathrm{COC}$ and fibrous aragonite are distinctly different (compositionally as well as isotopically) and that $\mathrm{COC}$ are further away from thermodynamic equilibrium than fibrous aragonite [Meibom et al., 2006; Rollion-Bard et al., 2003a; Sinclair et al., 2006]. In absence of a non-biological model that offers an explanation for these recent micro-analytical observations, it is proposed instead that the data indicate differential trans- 
port and incorporation of major and trace elements into the skeleton.

[10] Strontium is in solid solution in the $\mathrm{CaCO}_{3}$ structure [Allison et al., 2005] and a strong correlation is observed between $\mathrm{Ca}$ and $\mathrm{Sr}$ (Figure 3c). Towards the COC, the ${ }^{88} \mathrm{Sr}^{+}$ signal drops because the carbonate phase is increasingly diluted by the embedded organics. However, if the carbonate-to-organics abundance ratio was the only changing parameter along the traverse, the $\mathrm{Sr} / \mathrm{Ca}$ ratio should be essentially constant. Nonetheless, there is a significant residual $\mathrm{Sr} / \mathrm{Ca}$ variability (on the order of $15-25 \%$ ) that is much larger than the analytical precision $( \pm 2-3 \% ; 1 \sigma)$ and that cannot be explained by changes in the carbonate/ organics ratio (Figure 3c). These $\mathrm{Sr} / \mathrm{Ca}$ variations, which are not correlated with $\mathrm{Mg} / \mathrm{Ca}$, most likely result from biological processes capable of changing the $\mathrm{Sr} / \mathrm{Ca}$ ratio of the skeleton on sub-daily timescales. It has been argued that $\mathrm{Sr}^{2+}$ and $\mathrm{Ca}^{2+}$ are transported across the calicoblastic cell layer through the same voltage sensitive, transcellular channel [Ferrier-Pages et al., 2002; Tambutté et al., 1996]. However, because the $\mathrm{Sr} / \mathrm{Ca}$ ratio fluctuates both positively and negatively relative to the mean and does not correlate with the skeletal ultrastructure (Figure 2), we propose that biological processes other than this particular transport mechanism are important on short timescales; perhaps on timescales characteristic of cellular metabolic turnover rates. The observed lack of correlation between $\mathrm{Mg}$ and $\mathrm{Sr}$ strongly suggests that these two elements have dramatically different transport mechanisms or pathways from the environment into the skeleton. Similarly, $\mathrm{S}$ is not correlated with $\mathrm{Mg}$. The $\mathrm{S}$ distribution shows clear oscillations in the fibrous aragonite but, unlike $\mathrm{Mg}$, there is no obvious correlation with the layered ultra-structure. The factors that control the incorporation of sulfated polysaccharides into the skeleton are unknown. However, it is clear that these organic molecules are incorporated into the skeleton with a high degree of spatial and temporal control because COC and fibrous aragonite systematically have different concentrations of S [Cuif et al., 2003; Meibom et al., 2006].

[11] From this and other recent micro-analytical studies it is evident that the chemistry of the bulk coral exoskeleton is under very strong biological influence and that chemical (and stable isotope) variations are strongly coupled with the skeletal ultra-structure [Allison, 1996; Allison et al., 2005; Cohen et al., 2001; Cuif et al., 2003; Meibom et al., 2004, 2006; Rollion-Bard et al., 2003b; Sinclair, 2005]. This raises a fundamental question. Why are correlations often observed between seasonal time-series of skeletal traceelement concentrations and environmental factors (e.g., sea-surface temperature) when, at the ultra-structure level, the incorporation of these trace-elements is clearly not controlled directly by these environmental factors? Transportation of different elements into the skeleton likely takes place across trans-cellular, often protein-mediated pathways and/or in vesicle shuttles [Allemand et al., 2004; Erez, 2003]. These transport mechanisms are sensitive to temperature variations. In general, cellular properties such as membrane composition, fluidity, membrane-protein activities and metabolic processes are temperature sensitive [McKinley and Hazel, 2000; Tchernov et al., 2004; Vigh et al., 2005]. Most likely, it is the complex biological response to changes in water temperature (and other envi- ronmental parameters, such as nutrition) that introduces seasonal and sub-seasonal variations in skeletal chemistry. Importantly, the classic, physio-chemical formalism for inorganic carbonate precipitation does not offer an adequate or relevant description of these processes. A fundamentally new conceptual approach to coral-derived paleoenvironmental proxies is therefore needed. The intimate relationship between biological processes at the cellular level and exoskeletal composition must be understood because it carries the potential for greatly improved paleoclimatology.

[12] Acknowledgments. We thank Joe Wooden and Charlie Bacon for making carbonate standards available. This work was supported in part by a grant from the Agence National de la Recherche. Reviews by Dan Sinclair and two anonymous reviewers improved the manuscript.

\section{References}

Allemand, D., et al. (2004), Biomineralization in reef-building corals: From molecular mechanisms to environmental control, C.R. Palevol., 3, 453467.

Allison, N. (1996), Comparative determination of trace and minor elements in coral aragonite by ion microprobe analysis, with implications from Phuket, southern Thailand, Geochim. Cosmochim. Acta, 60, 3457-3470.

Allison, N., et al. (2005), Strontium in coral aragonite: 3. Sr coordination and geochemistry in relation to skeletal structure, Geochim. Cosmochim. Acta, 69, 3801-3811.

Amiel, A. J., et al. (1973), Distribution and nature of incorporation of trace elements in modern aragonitic corals, Sedimentology, 20, 47-64.

Brown, B. E., et al. (1983), The nature and construction of skeletal spines in Pocillopora dmicornis (Linnaeus), Coral Reefs, 2, 81-89.

Bryan, W. H., and D. Hill (1941), Spherulitic crystallization as a mechanism of skeletal growth in the hexacorals, Proc. R. Soc. Queensl., 52, 7891.

Clode, P. L., and A. T. Marshall (2002), Low temperature FESEM of the calcifying interface of a scleractinian coral, Tissue Cell, 34, 187-198.

Clode, P. L., and A. T. Marshall (2003), Skeletal microstructure of Galaxea fascicularis exsert septa: A high-resolution SEM study, Biol. Bull., 204, $146-154$

Cohen, A. L., G. D. Layne, S. R. Hart, and P. S. Lobel (2001), Kinetic control of skeletal $\mathrm{Sr} / \mathrm{Ca}$ in a symbiotic coral: Implications for the paleotemperature proxy, Paleoceanography, 16, 20-26.

Cohen, A. L., G. A. Gaetani, T. Lundälv, B. H. Corliss, and R. Y. George (2006), Compositional variability in a cold-water scleractinian, Lophelia pertusa: New insights into "vital effects", Geochem. Geophys. Geosyst., 7, Q12004, doi:10.1029/2006GC001354.

Constantz, B. R., and S. Weiner (1988), Acidic macromolecules associated with the mineral phase of scleractinian coral skeletons, J. Exp. Zool., 248, $253-258$.

Cuif, J.-P., and Y. Dauphin (2005), The environmental recording unit in coral skeletons-A synthesis of structural and chemical evidences for a biochemically driven, stepping-growth process in fibres, Biogeosciences, $2,61-73$.

Cuif, J.-P., et al. (2003), XANES mapping of organic sulfate in three scleractinian coral skeletons, Geochim. Cosmochim. Acta, 67, 75-83.

Davis, K. J., et al. (2004), Morphological consequences of differential $\mathrm{Mg} 2+$ incorporation at structurally distinct steps on calcite, Am. Mineral., $89,714-720$.

Domart-Coulon, I., et al. (2006), Comprehenisve characterization of skeletal tissue growth anomalies of the finger coral Porites compressa, Coral Reefs, 25, 531-543, doi: 10.1007/s00338-006-0133-6.

Epstein, S., et al. (1953), Revised carbonate-water isotopic temperature scale, Geol. Soc. Am. Bull., 64, 1315-1326.

Erez, J. (2003), The source of ions for biomineralization in foraminifera and their implications for paleoceanographic proxies, in Biomineralization, edited by P. M. Dove et al., pp. 115-149, Mineral. Soc. of Am. and Geochem. Soc., Washington, D. C.

Ferrier-Pages, C., et al. (2002), Kinetics of strontium uptake in the scleractinian coral Stylophora pistillata, Mar. Ecol. Prog. Ser., 245, 93-100.

Gaetani, G. A., and A. L. Cohen (2006), Element partitioning during precipitation of aragonite from seawater: A framework for understanding paleoproxies, Geochim. Cosmochim. Acta, 70, 4617-4634.

Hart, S. R., and A. L. Cohen (1996), An ion probe study of annual cycles of $\mathrm{Sr} / \mathrm{Ca}$ and other trace elements in corals, Geochim. Cosmochim. Acta, 60, 3075-3084 
Johnston, I. S. (1980), The ultrastructure of skelatogenesis in hermatypic corals, Int. J. Cytology, 67, 171-214.

Kinsman, D. J. J., and H. D. Holland (1969), The co-precipitation of cations with $\mathrm{CaCO}_{3}--\mathrm{IV}$. The co-precipitation of $\mathrm{Sr}^{+}$with aragonite between $16^{\circ} \mathrm{C}$ and $96^{\circ} \mathrm{C}$, Geochim. Cosmochim. Acta, 33, 1-17.

Le Tissier, M. D. A. (1990), The ultrastructure of the skeleton and skeletogenic tissues of the Temperate coral Caryophyllia Smithii, J. Mar. Biol. Assoc. U.K., 70, 295-310.

McKinley, S., and J. R. Hazel (2000), Does membrane fluitidy contribute to thermal compensation of beta-adrenergic signal transduction in isolated trout hepatocytes?, J. Exp. Biol., 203, 631-640.

Meibom, A., et al. (2003), Monthly Strontium/Calcium oscillations in symbiotic coral aragonite: Biological effects limiting the precision of the paleotemperature proxy, Geophys. Res. Lett., 30(7), 1418, doi:10.1029/ 2002 GL016864.

Meibom, A., et al. (2004), Distribution of magnesium in coral skeleton, Geophys. Res. Lett., 31, L23306, doi:10.1029/2004GL021313.

Meibom, A., et al. (2006), Vital effects in coral skeletal composition display strict three-dimensional control, Geophys. Res. Lett., 33, L11608, doi:10.1029/2006GL025968.

Mitshuguchi, T., et al. (1996), Mg/Ca thermometry in coral skeletons, Science, 274, 961-963.

Muscatine, L., et al. (1997), Morphology of coral desmocystes, cells that anchor the calicoblastic epithelium to the skeleton, Coral Reefs, 16, $205-$ 213.

Raz-Bahat, M., et al. (2006), In vivo light-microscopic documentation for primary calcification processes in the hermatypic coral Stylophora pistillata, Cell Tissue Res., 325, 361-368, doi:10.1007/s00441-006-0182-8.

Rollion-Bard, C., et al. (2003a), Microanalysis of C and O isotopes of azooxanthellate and zooxanthellate corals by ion microprobe, Coral Reefs, 22, 405-415.

Rollion-Bard, C., et al. (2003b), pH control on oxygen isotopic composition of symbiotic corals, Earth. Planet. Sci. Lett., 215, 275-288.
Sinclair, D. J. (2005), Correlated trace element "vital effects" in tropical corals: A new geochemical tool for probing biomineralization, Geochim. Cosmochim. Acta, 69, 3265-3284.

Sinclair, D., et al. (2006), A biological origin for climate signals in coralsTrace element "vital effects" are ubiquitous in scleractinian coral skeletons, Geophys. Res. Lett., 33, L17707, doi:10.1029/2006GL027183.

Smith, S. V., et al. (1979), Strontium-Calcium thermometry in coral skeletons, Science, 204, 404-407.

Stolarski, J. (2003), Three-dimensional micro- and nanostrucural characteristics of the scleractinian coral skeleton: A biocalcification proxy, Acta Palaeontol. Polonica, 48, 497-530.

Swart, P. K., and J. J. Leder (1996), The utility of isotopic signatures in coral skeletons, Paleontol. Soc. Pap., 1, 249-291.

Tambutté, E., et al. (1996), A compartmental approach to the mechanism of calcification in hermatypic corals, J. Exp. Biol., 199, 1029-1041.

Tchernov, D., et al. (2004), Membrane lipids of symbiotic algae are diagnostic of sensitivity to thermal bleaching in corals, Proc. Natl. Acad. Sci. U.S.A., 101, 13,531-13,535.

Vigh, L., et al. (2005), The significance of lipid composition for membrane activity: New concepts and ways of assessing function, Prog. Lipid Res., 44, 303-344.

Weiner, S., et al. (2003), Biologically formed amorphous calcium carbonate, Connective Tissue Res., 44, 214-218.

B. Constantz, R. Dunbar, and F. Houlbreque, Department of Geological and Environmental Sciences, Stanford University, Stanford, CA 94305, USA.

J.-P. Cuif and Y. Dauphin, UMR 8148, IDES, Université Paris XI, Bat. 504 Géologie, F-91495 Orsay, France.

A. Meibom and S. Mostefaoui, Laboratoire d'Etude de la Matiere Extraterrestre USM 0205, Muséum National d'Histoire Naturelle, Case Postale 52, 57 rue Cuvier, 75005 Paris, France. (meibom@mnhn.fr) 